\title{
Expression of Arabidopsis gdh 2 gene depends on activity of alternative electron transfer pathway in mitochondria
}

\author{
Siberian Institute of Plant Physiology and Biochemistry \\ Siberian Branch of the Russian Academy of Sciences \\ 132, Lermontova Str., Irkutsk, Russian Federation, 664033 \\ vslav@inbox.ru
}

V. I. Tarasenko, E. Yu. Garnik, Yu. M. Konstantinov

\begin{abstract}
Aim. We studied the expression level of gdh2 gene, encoding subunit of mitochondrial glutamate dehydrogenase, in Arabidopsis suspension culture cells with genetically modified level of alternative oxidase AOX1a. Methods. Polymerase chain reaction, Northern-blotting. Results. The treatment with main electron transfer pathway inhibitor antimycin A led to an increase in gdh2 transcript level in the wild-type cells and the cells with decreased level of alternative oxidase, but not in the cells with elevated level of alternative oxidase. Conclusions. It is known that an increase in alternative oxidase level in the plant cell results in more oxidized state of ubiquinone pool in respiratory chain. Therefore, the obtained results support the earlier proposed model according to which the expression level of gdh2 gene depends on the redox state of ubiquinone pool.
\end{abstract}

Keywords: Arabidopsis thaliana, electron transport chain, alternative oxidase, glutamate dehydrogenase, antimycin $A$.

Introduction. The results of recent studies demonstrate that the expression of a number of plant nuclear genes encoding the mitochondrial proteins are regulated by the functional state of mitochondria. The inhibition of the electron transport chain (ETC) of the mitochondria or the impairment of the functions of respiratory processes due to some mutations induces the genes encoding the alternative oxidases (AO), alternative $\mathrm{NAD}(\mathrm{P}) \mathrm{H}$-dehydrogenases, the components of mitochondrial systems of protein import, and some other proteins [1-3]. The mechanisms of this retrograde regulation regarding the expression of $\mathrm{AO}$ genes have been studied in detail. Numerous studies in this field demonstrated high complexity and specificity of the expression activation process. For instance, each of three isoforms of the maize alternative oxidase is specifically induced in response to the inhibition of a specific complex of the respiratory chain [4]. The induction of AO genes is affected by the level of gene-

(C) Institute of Molecular Biology and Genetics, NAS of Ukraine, 2012 ration of reactive oxygen species (ROS) in ETC of the mitochondria and is inhibited by the inhibitors of protein kinases and/or protein phosphatases depending on the gene $[3,5]$.

We have previously shown [6] that the expression of gdh2 gene encoding beta-subunit of the mitochondrial glutamate dehydrogenase is also determined by the state of the respiratory chain. The treatment of Arabidopsis thaliana cell suspension with antimycin A - the inhibitor of complex III of the respiratory chain for 2 hours leads to the increase in the $g d h 2$ transcript level. The inhibition of complex I with the addition of rotenon does not have any effect on the transcript level. At the same time the treatment of complex IV with potassium cyanide leads to the increase in the transcript level. Therefore, the expression of $g d h 2$ gene is likely to respond to the changes in the state of the respiratory chain on the site localized between complexes I and III. The absence of the activation of gene expression during the treatment of the cell suspension with hydrogen peroxide and prooxidant paraquat as well as the results 
of experiments with antioxidants allow the assumption that the observed effect is not associated with the increase in the content of the reactive oxygen species, generated while inhibiting ETC. The obtained data demonstrate that the initial signal leading to the induction of the $g d h 2$ expression is the change in the redox state of the specific segment of the respiratory chain.

The respiratory chain of the plant mitochondria has a number of peculiarities, the main of them being the presence of alternative electron transfer pathways bypassing the main respiratory complexes. The most important pathway is the alternative oxidase - a homodimer protein, capable of accepting electrons from ubiquinone, and transferring them directly to oxygen, bypassing two of three oxidation and phosphorylation coupling sites in ETC [7].

One of AO functions is prevention of the ETC over-reduction and the associated increase in the level of ROS formed in the respiratory chain [5]. The informative system for the determination of a role of the respiratory chain components may be the transgene plants with the modified level of expression of the genes encoding these proteins. For instance, the application of the suspension cultures of tobacco transgene line cells provided reliable evidence of an important role of AO in the prevention of ROS formation by the respiratory chain. The transgene lines, characterized by overexpression and decreased expression of $\mathrm{AO}$, have considerably lower and higher levels of ROS, respectively [8].

The current work was aimed at study of the level of $g d h 2$ gene expression in the suspension cultures of the cells obtained from the transgene Arabidopsis plants with the decreased and increased AO content. The work demonstrates that the treatment with antimycin A leads to the differential changes of the $g d h 2$ transcript level in cells of the investigated lines, which testifies to the participation of the alternative electron transport pathway in the regulation of the glutamate dehydrogenase expression.

Materials and Methods. Arabidopsis seeds of Col-0 line (wild type plants, Columbia ecotype), AS-12 line (plants transformed by the construct expressing aoxla gene in the antisense orientation under the control of CaMV 35S promotor) and XX-2 line (plants, transformed by the construct expressing aoxla gene in the sense orientation) were obtained from Nottingham Arabidopsis Stock Centre (NASC, UK). The cultivation in the soil culture was performed at $23^{\circ} \mathrm{C}, 16$ daylight hours and the light intensity of $100 \mu \mathrm{M} \mathrm{m}^{-2} \mathrm{~s}^{-1}$, as described previously [9]. The substrate was the mixture of the compost for houseplants and the vermiculite in 2:1 ratio.

The suspension culture was obtained from the sterile 7-day-old Arabidopsis seedlings. 10-15 seedlings were placed into $70 \mathrm{ml}$ of the nutrient medium based on MS salts with the addition of thiamine $-1 \mathrm{mg} / \mathrm{l}$, pyridoxin $-0.5 \mathrm{mg} / 1$, nicotinic acid $-0.5 \mathrm{mg} / 1$, inositol - $100 \mathrm{mg} / 1$, sucrose - $30 \mathrm{~g} / 1$, 2,4-dichlorophenoxyacetic acid $-0.3 \mathrm{mg} / \mathrm{l}$. The cultivation was performed at $25{ }^{\circ} \mathrm{C}$ in darkness on the rotational shaker with the rotation frequency of $60 \mathrm{rpm}$. 3-4 weeks later the cells were placed into $70 \mathrm{ml}$ of fresh nutrient medium of the same composition and were further subcultivated every 12 days in the abovementioned conditions. The experiments were conducted on the $6^{\text {th }}$ day of subcultivation in three repeats. The viability of the suspension culture was estimated by the absorption of Evans Blue dye by the dead cells [10].

The screening of plants and cells for the presence of the genetic constructs was performed using PCR. The primers AOX.for (5'-GATGATAACTCGCGGTGGA GCCAA) and AOX.rev (5'-GCCGAATCCAAGTAT GGCTTAAGC), specific for the encoding sequence of aoxla gene, as well as the primers CMV.for (5'-CGAAAGGCTCAGTCGAAAGACTGG) and NOS.rev (5'-GACACCGCGCGCGATAATTTATC C), specific for the vector sequence, were used in the work. PCR with the pair of primers CMV.for and AOX.rev allowed revealing the presence of the construct containing the sequence of aoxla gene in the sense orientation, and PCR with the pair of primers AOX. rev and NOS.rev - the presence of the construct with aoxla in the antisense orientation. DNA amplification was performed in standard conditions. The total DNA of the individual plant, obtained according to [11], was used as a PCR substrate.

To extract total RNA the suspension culture cells were ground in the liquid nitrogen with subsequent addition of $450 \mu \mathrm{l}$ of TE buffer, $50 \mu \mathrm{l}$ of SDS (10\%) and $500 \mu \mathrm{l}$ of phenol (ICN). Further extraction was performed by the previously described hot phenol 


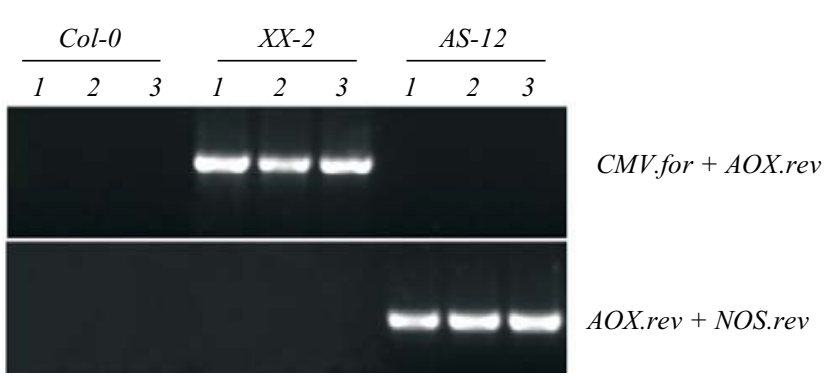

Fig. 1 PCR analysis of individual plants (1-3) of wild type (Col-0) and the lines with elevated $(X X-2)$ and reduced $(A S-12)$ levels of AOX1a. The combination of primers CMV.for and AOX.rev was used to reveal the construct with aoxla gene in the sense orientation; the combination of primers AOX.rev and NOS.rev - to reveal the construct with aoxla in the antisense orientation.

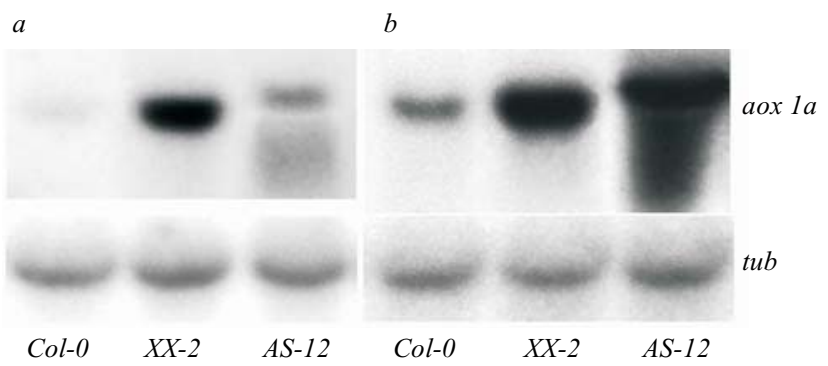

Fig. 2 Northern blotting of aoxla gene expression in plants $(a)$ and suspension cell cultures $(b)$ of wild type line $(\mathrm{Col}-0)$ and the lines with elevated $(X X-2)$ and reduced $(A S-12)$ levels of AOX1a. The level of beta-tubulin gene transcript (tub) is used as a control.

extraction [12]. The total RNA was extracted from the plants using Trizol (TRI agent, ICN) in accordance to the manufacturer's instructions. The total RNA was separated in $1.2 \%$ agarose gel in denaturating conditions and transferred to the nylon membrane Hybond $\mathrm{N}$ (Amersham, USA). The hybridization and staining of DNA fragments were performed according to [6]. cDNA, extracted according to [13], was used as a substrate to obtain DNA probes to genes aoxla and tub.

Results and Discussion. The confirmation of the presence and expression of the transgene in plants and cell cultures of the investigated lines. The Arabidopsis lines transformed by the constructs carrying aoxla gene under the control of CAMV35S promotor in the sense (XX-2) or antisense orientation (AS-12) were previously established [14]. It is noteworthy that regardless of the presence of the genes encoding five different isoforms of alternative oxidase in the Arabidopsis genome, only AOX1a isoform is expressed at a high level and is actively induced by stresses or the inhibition of the main electron transfer pathway [1].
Therefore, the plants with the modified level of expression of AOX1a protein are an adequate model system for the study of the consequences of changes in the activity of the alternative electron transfer pathway. The seeds of the abovementioned lines (T3 generation) were obtained from the generally available seedbank for Arabidopsis. The progeny of plants grown from these seeds (T4 generation) was used in the subsequent studies. The seedlings of this generation were used to obtain the suspension cultures of the investigated lines.

At the first stage of work it was essential to confirm the preservation and expression of the foreign genetic material in the investigated plants and suspension cultures. The verification of the presence of DNA insertion in the genome of plants by PCR with the combinations of primers specific for each genetic construct secures a positive result (Fig. 1). Then we investigated the level of aoxla transcript in each of three lines by the Northern hybridization. As seen in Fig. 2, the content of aoxla transcript in the leaves of individual plants and the cells of XX-2 line suspension was multifold higher compared to the wild type line (Col-0). The transcript corresponding to the size of aoxla gene transcript was not found in the plants and cells of AS-12 line. However, the samples contained the transcript of a larger size corresponding to the antisense construction expression product as well as the smear corresponding probably to the products of the degradation of aoxla transcript in vivo. Based on the obtained data we made a conclusion on the preservation of a high level of the transformed genetic material expression in both plants and suspension culture cells.

The investigation of the level of gdh2 gene expression in the suspension cell cultures. The study of the gdh2 gene transcript level in the suspensions of cells with modified AO level and wild type cells demonstrated that in normal conditions the gene is expressed at the similar level in all the three lines (Fig. 3). As we demonstrated previously that the expression of $g d h 2$ is induced in the presence of the inhibitor of respiratory complex III antimycin A, our next experiment was aimed at the comparison of the level of the $g d h 2$ transcripts in three lines during the treatment with this compound. As see in Fig. 3, the expression level of the investigated gene under the impact of antimycin A changed in different ways. The content of $g d h 2$ 


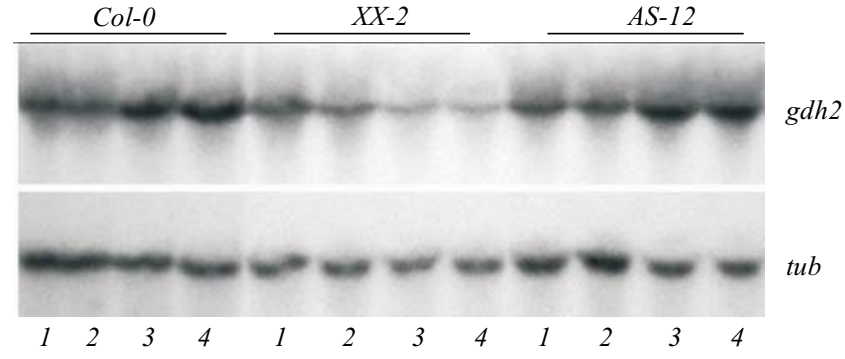

Fig. 3 Northern blotting of $g d h 2$ gene expression in the suspension cultures of wild type cells ( $\mathrm{Col}-0)$ and the lines with elevated $(X X-2)$ and reduced $(A S-12)$ levels of alternative oxidase in normal conditions and during the treatment with antimycin A. The cells were incubated for $3(1,3)$, and $5(2,4)$ hours in the absence $(1,2)$ and in the presence $(3,4)$ of antimycin $\mathrm{A}(10 \mu \mathrm{M})$. The level of beta-tubulin gene transcript (tub) is used as a control.

transcripts increased upon the addition of antimycin A to the suspensions of wild type cells and the cells of the line with the decreased level of alternative oxidase. However, the effect of antimycin A on the cells of the line with the increased level of alternative oxidase does not lead to any elevation of the transcript level. Moreover, the addition of antimycin leads to some decrease in the level of $g d h 2$ gene expression. Therefore, the change in the direction of $g d h 2$ gene response to the inhibitor treatment of the main electron transfer pathway is observed in conditions of the enhanced activity of the alternative respiratory pathway which is characteristic for XX-2 cells [14].

The activation of the alternative oxidase is known to lead to the augmented electron flow via the alternative respiratory pathway and thus the reduction of the flow via the main respiratory complexes. This results in a more oxidized state of ubisemiquinone pool in ETC [7]. Previously we used the results of our experiments with inhibitors of different ETC sites to suggest the model according to which the redox-state of ubiquinone pool serves as the main source of the signal about the gdh2 gene induction [6]. According to this hypothesis, the over-reduction of ubiquinone pool, occurring either due to the chemical inhibition of complexes III and IV or due to different stresses under in vivo conditions, leads to the elevated level of $g d h 2$ gene expression. As the enhanced $\mathrm{AO}$ activity in XX-2 cells leads to a more oxidized state of ubiquinone pool, the absence of $g d h 2$ expression induction during the inhibition of the main electron transfer pathway is in good agreement with the suggested hypothesis.
Conclusions. The results of the experiments with Arabidopsis transgene lines testify to the plausibility of the previously suggested model according to which the level of expression of the nuclear gene $g d h 2$ depends on the redox state of ubiquinone pool in the mitochondrial respiratory chain. The obtained data demonstrate that the state of both the main and the alternative pathways of electron transfer could play a role of the modulator of $g d h 2$ expression level. As the activity of the alternative electron transfer pathway in the plant cell changes due to the effect of many factors, including different stress es, this mechanism may play an important role in the regulation of glutamate dehydrogenase expression in vivo.

Acknowledgment. The work was performed with the financial support of the Integration Interdisciplinary Project, SB of RAS No. 59, grant of RFBR 12-0401148-a, and the Ministry of Education and Science of the Russian Federation (2012-1.1-12-000-2008-6400).

\section{В. И. Тарасенко, Е. Ю. Гарник, Ю. М. Константинов}

Экспрессия гена $g d h 2$ арабидопсиса зависит от

активности альтернативного пути переноса электронов

в митохондриях

Сибирский институт физиологии и биохимии растений

Сибирского Отделения РАН

ул. Лермонтова, 132, Иркутск, Российская Федерация, 664033

Резюме

Цель. Исследование уровня экспрессии гена gdh2, кодирующего субъединииу митохондриальной глутаматдегидрогеназы, в суспензионных культурах клеток арабидопсиса с генетически модифицированньм уровнем альтернативной оксидазы АOX1а. Методы. Полимеразная цепная реакиия, Нозерн-блоттинг. Результаты. Показано, что при обработке ингибитором основного пути переноса электронов антимицином $A$ содержание транскриптов gdh2 возрастает в клетках дикого типа и в клетках со сниженным уровнем альтернативной оксидазы, однако остается неизменным в клетках с ее повышенным содержанием Выводы. Поскольку увеличенный уровень альтернативной оксидазы приводит к уменьшению степени восстановленности пула убихинона в дыхательной цепи, полученные результаты свидетельствуют в пользу модели, согласно которой уровень экспрессии гена gdh2 зависит от редокс-состояния убихинонового пула

Ключевые слова: Arabidopsis thaliana, электронно-транспортная иепь, альтернативная оксидаза, глутаматдегидрогеназа, антимицин $A$. 


\section{B. І. Тарасенко, С. Ю. Гарник, Ю. М. Константинов}

Експресія гена $g d h 2$ арабідопсису залежить від активності альтернативного шляху перенесення електронів у мітохондріях

\section{Резюме}

Мета. Дослідити рівень експресї гена gdh2, кодуючого субодинииюю мітохондріальної глутаматдегідрогенази, у суспензійних культурах клітин арабідопсису з генетично модифікованим рівнем альтернативної оксидази АОХІа. Методи. Полімеразна ланиңюгова реакиія. Результати. Показано, щчо за обробки інгібітором основного иляху перенесення електронів антиміцином $A$ вміст транскриптів gdh2 зростає у клітинах дикого типу $і$ в клітинах зі зниженим рівнем альтернативної оксидази, однак він лишається незмінним у клітинах з ї̈ підвищеним вмістом. Висновки. Оскільки збільшений рівень альтернативної оксидази спричиняє зменшення ступеня відновлення пулу убіхінону у дихальному ланцюгу, отримані резудбтати свідчать на користь моделі, згідно з якою рівень експресї гена gdh2 залежить від редокс-стану убіхінонового пулу.

Ключові слова: Arabidopsis thaliana, електронно-транспортний ланцюг, альтернативна оксидаза, глутаматдегідрогеназа, антиміцин $A$.

\section{REFERENCES}

1. Clifton R., Lister R., Parker K. L., Sappl P. G., Elhafez D., Millar A. H., Day D. A., Whelan J. Stress-induced co-expression of alternative respiratory chain components in Arabidopsis thaliana // Plant Mol. Biol.-2005.-58, N 2.-P. 193-212.

2. Lister R., Chew O., Lee M. N., Heazlewood J. L., Clifton R., Parker K. L., Millar A. H., Whelan J. A transcriptomic and proteomic characterization of the Arabidopsis mitochondrial protein im- port apparatus and its response to mitochondrial dysfunction // Plant Physiol.-2004.-134, N 2.-P. 777-789.

3. Vanlerberghe G. C., Robson C. A., Yip J. Y. Induction of mitochondrial alternative oxidase in response to a cell signal pathway down-regulating the cytochrome pathway prevents programmed cell death // Plant Physiol.-2002.-129, N 4.-P. 18291842.
4. Karpova O. V., Kuzmin E. V., Elthon T. E., Newton K. J. Differential expression of alternative oxidase genes in maize mitochondrial mutants // Plant Cell.-2002.-14, N 12.-P. 3271-3284.

5. Vanlerberghe G. C., McIntosh L. Alternative oxidase: from gene to function // Annu. Rev. Plant Physiol. Plant Mol. Biol.1997.-48.-P. 703-734.

6. Tarasenko V. I., Garnik E. Yu., Shmakov V. N., Konstantinov Yu. $M$. Induction of Arabidopsis gdh2 gene expression during changes in redox state of the mitochondrial respiratory chain // Biochemistry (Moscow).-2009.-74, N 1.-P. 47-53.

7. Moller I. M. Plant mitochondria and oxidative stress: electron transport, NADPH turnover, and metabolism of reactive oxygen species // Annu. Rev. Plant Physiol. Plant Mol. Biol.-2001.52.-P. 561-591.

8. Maxwell D. P., Wang Y., McIntosh L. The alternative oxidase lowers mitochondrial reactive oxygen production in plant cells // Proc. Natl Acad. Sci. USA.-1999.-96, N 14.-P. 8271-8276.

9. Tarasenko V. I., Garnik E. Yu., Konstantinov Yu. M. Characterization of Arabidopsis mutant with inactivated gene coding for Fe-S subunit of mitochondrial respiratory chain complex I // Russ. J. Plant Physiol.-2010.-57, N 3.-P. 392-400.

10. Baker C. J., Mock N. M. An improved method for monitoring cell death in cell suspension and leaf disc assays using evans blue // Plant Cell. Tissue and Organ. Culture.-1994.-39.-P. $7-12$.

11. Doyle J. J., Doyle J. L. A rapid isolation program for small quantities of fresh leaf tissue // Phytochem. Bull.-1987.-19.-P. 11- 15.

12. Garnik E. Yu., Tarasenko V. I., Kobsev V. F., Konstantinov Yu. M. Differential expression of maize mitochondrial genes as dependent on mitochondria redox state // Russ. J. Plant Physiol.2006.-53, N 4.-P. 463-468.

13. Tarasenko V. I., Katyshev A. I., Kobzev V. F., Konstantinov Yu. $M$. Comparative analysis of nuclear and mitochondrial DNA topoisomerase I from Zea mays // Mol. Biol. (Mosk.).-2008.42, N 1.-P. 88-95.

14. Umbach A. L., Fiorani F., Siedow J. N. Characterization of transformed Arabidopsis with altered alternative oxidase levels and analysis of effects on reactive oxygen species in tissue // Plant Physiol.-2005.-139, N 4.-P. 1806-1820.

Received 10.05.12 